\title{
HISTORY AND DEVELOPMENT OF ANAESTHESIOLOGY (WITH RESUSCITATION AND INTENSIVE MEDICINE) IN THE REPUBLIC OF MACEDONIA
}

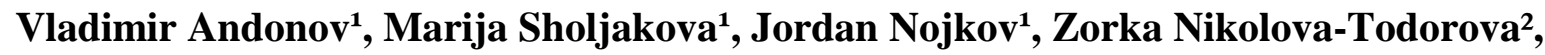 Mirjana Shosholcheva ${ }^{2}$, Andrijan Kartalov², Biljana Kuzmanovska ${ }^{2}$}

${ }^{1}$ Faculty of Medicine, Ss Cyril and Methodius University, Skopje, R. Macedonia, Pensioner, independent researcher

${ }^{2}$ Clinic of Anaesthesiology, Reanimation and Intensive Care, Faculty of Medicine, Ss Cyril and Methodius University, Skopje, R. Macedonia

Corresponding Author: Dr. Andrijan Kartalov, Clinic of Anaesthesiology, Reanimation and Intensive Care, Faculty of Medicine, Ss Cyril and Methodius University, Skopje, Republic of Macedonia. Tel. +389 (0)2 31125 06, Fax: +389 (0)2 31125 06, E-mail: andrian_kartalov@yahoo.com

\begin{abstract}
Aim: To present a chronological overview of the most important events and actors that have marked the history of anaesthesiology and intensive treatment in R. Macedonia since its beginnings in the $1950 \mathrm{~s}$.

Method: Retrospective study based on archive materials, published literature and jubilee publications, as well as the memories of individuals who have worked in the field of anaesthesiology in the past period.

Results: Between the two World Wars the first anaesthesia procedures were handled by surgeons. After World War II, the development of anaesthesia in R. Macedonia could be divided into two periods: before 1965 and after 1965. Before 1965 anaesthesia was mainly given by technicians trained on courses, and after this year anaesthesiology was taken over by anaesthesiologists who had specialized at the Faculty of Medicine in Skopje. In 1985 the number of anaesthesiologists was 100, and today it exceeds 250. The most important figures in the history of Macedonian anaesthesiology are: Dr. Risto Ivanovski, who worked from 1954 \pm 78 , and Prof. Dr. Vladimir Andonov, who worked as an anaesthesiologist from $1965 \pm 99$. Both of them are doyens who contributed a lot to the development of the anaesthesiology service and education of anaesthesiologists in R. Macedonia. Intensive treatment had started in 1955, but in real terms it has been performed since 1966, when artificial ventilators were introduced. The modern Intensive Care Department was opened at the Surgical Clinic in 1995 and it was followed in other hospitals in the state. The Department of Anaesthesiology has existed since 1975, and it has made a huge contribution to the education of professionals who apply modern principles in emergency medicine and intensive care.

Conclusion: From modest beginnings in the 1950s, anaesthesiology today in R. Macedonia has developed well organized activity that successfully follow the trends of modern medicine in the field of anesthesiology, resuscitation, intensive care and pain treatment.
\end{abstract}

Key words: anaesthesiology, resuscitation, intensive care, pain treatment, Republic of Macedonia, history.

\section{Introduction}

Anaesthesiology is a young medical discipline and has come about as a practical need of modern surgery [1]. Its origins are linked with the name of the ingenious American dentist William Morton, who performed the first demonstration of anaesthesia in the world by inhaled ether as a surgical anesthetic, in Boston, USA, in 1846. According to verified documentation there is an interesting datum that Croatian anaesthesiologists performed the first anesthesia with ether on the Balkans $[2,3]$ in the region of Zadar 6 months later, namely on March 13, 1847. Anaesthesia was given for a 
long period of time by medical technicians (anaesthetists) under the control of surgeons everywhere in the world. In 1947 anaesthesiology was introduced as an autonomous medical specialty in Europe. However, during the following decades, the enormous development of surgery, the increasing number of invasive procedures, and the development of artificial ventilation have placed this discipline in the centre of modern medicine, without which no modern hospital could be imagined. So today, anaesthesia is a constituent part of the healthcare mission of each high-technology medical institution and represents an irreplaceable part in the delivery of modern medical practice in surgery, intensive care, and pain treatment in patients.

The main aim of this article is to present a chronological overview of the most important events and activities in the history of anaesthesiology together with intensive treatment in R. Macedonia since its beginnings in the 1950s. The second aim is to emphasize the role of the main persons that marked the development of anaesthesiology and resuscitation in our country.

\section{Method}

A retrospective study based on archive materials, published literature, University bulletins and jubilee publications, as well as the memories of individuals who have worked in the field of anaesthesiology in the past period in R. Macedonia.

\section{Results and discussion}

\section{Initial historical data related to health} care and anaesthesiology in R. Macedonia

Concerning the past, it deserves attention to dedicate a few words to the fresco drawing in the church St. Spas in Skopje where it is shown how God breathes air into the mouth of Adam, the first human. Xylographers worked on this fresco drawing according to the data from the Bible the first book of Moses 1.2.7. This historical fact is applied in the contemporary approach of resuscitation by the method of breathing (inhaling) air to the victim/patient "mouth to mouth".

Data for the use of general ether anaesthesia on the territory of Serbia originates from 1896 [3]. It might be connected with the situation on the territory of the present Republic of Macedonia, which was a constituent part of the Ottoman Empire, and later of the Kingdom of
Yugoslavia. We could not find written documents, but we received indirect verbal information about the types of anaesthesia that were used in the 1920 s and the period which followed up to the end of the Second World War. By this oral history method, Prof. V. Andonov provided important information about the type of anaesthesia in Skopje in that period. He was told by Prof. A. Stavridis about the personal experience with anaesthesia of his mother Vera Stavridis. When she read an article in the weekly magazine "Ilustrirana Politika", in the mid 1970s, about the spinal anaesthesia administered by Prof. Dr L. Shendov for an artificial hip operation performed in Skopje by the orthopaedic surgeon Acad. Dr Lj. Serafimov, she reminded herself that as a young girl she had an attack of acute appendicitis in 1940. The operative intervention was done by her future husband, Dr. Sotir Stavridis. But she remembered that before the intervention, the surgeon had administered one injection in the spine and one injection in the region of the operative field. It might be concluded that the injection administered into the spine was spinal (sub-arachnoid) anaesthesia in addition to the local anaesthetic administered in the region of the operative intervention.

In any case, this period of development of anaesthesia, in general, remains unresolved and it is necessary to search for data and information in historical and private archives about the ways surgeons at that time gave anaesthesia. There are some data that solutions of cocaine (cocaine sol.), percaine and novocain were used as local anesthetics for infiltrative local anesthesia and regional spinal anesthesia. Certainly, at that period general anaesthesia, in the first instance with ether and later chloroform, pentothal and chlorethyl started to be used. It should be noted that anaesthesiology procedures were performed by younger surgeons, as well as by trained secondary-educated medical staff.

\section{Anaesthesiology development in $R$. Macedonia after the Second World War}

Anaesthesiology with resuscitation and intensive care, as a specialty in medicine in the world and in our country, experienced expansive development after World War II, thus achieving great progress [3]. The events that are important for the history of Macedonian anaesthesiology will be enumerated in chronological order. 
In the first years after World War II, when there was a need for an increased number of operative interventions, anaesthesia was predominantly given by trained secondary-educated medical staff (we would say very skilful). From 1960 an organized approach for the education of technicians started through longer courses with practical training which lasted for six months. The education took place at the department of anaesthesia and resuscitation at the Surgical Clinic in Skopje. For the needs of the military sanitation service, similar education was performed at the Military Hospital in Skopje, too. Later on, around 1965 and onwards, the duration of the courses lasted for a year. Such an approach was imposed because the number of doctors in R. Macedonia was very small and insufficient for the complex health needs of the population. Even the suggestions of the World Health Organization at that time supported this approach, recommending that anaesthesia should be given by medical technicians (anaesthetist) under the control of surgeons.

For this period of the history of anaesthesia, when anaesthetists performed this work, the choice of ether as an inhalation anaesthetic was crucial even in the hands of incompletely trained individuals because ether has a wide range of anaesthetic effects until it provokes severe complications. It is simple to use ether as it can be applied only by using the "Schimelbuch's" mask. This method of anaesthesia was called "pocket" anaesthesia (the bottle with ether in one pocket and the mask in the other one). Certainly, the most inconvenient side effect of it was irritable inhalation, causing a patient feelings of suffocation. It was not pleasant and safe even for the anaesthetists who applied ether anaesthesia, because they breathed a certain amount of ether and slept for hours after duty. Besides ether, chlorethyl (as a local anesthetic) was used, and rarely chloroform, too. Also this period was marked by the use of pentothal (barbiturate with a fast and short effect).

Some of the anaesthetists who worked for decades in the surgical hospitals in R. Macedonia in the 1960s and 1970s, and Prof. Dr. Vladimir Andonov personally worked with them and mentioned their names, are: Marche Drakulevska (later graduated in medicine and specialized in anaesthesiology), Vojo Siljanovski, Stojan Brzakov, Duska Arsova and many others.

In Europe, specialization as a physiciananaesthesiologist was first introduced in 1947. As long as up to 1947, aneasthesiology was considered an "easy learning" branch that could be learned in a few months, "on a course". In R. Macedonia, it was thus by the end of the $1960 \mathrm{~s}$ when doctors, specialists in anaesthesiology, finally took full responsibility in the area of anaesthesiology, reanimation and intensive care.

From the earliest beginnings of contemporary anaesthesiology in R. Macedonia, in the mid 1950s, the central figure is Dr. Risto Ivanovski (Box 1).

\section{Box 1. Dr. Risto Ivanovski, Associate Professor in Anesthesiology [4-7]

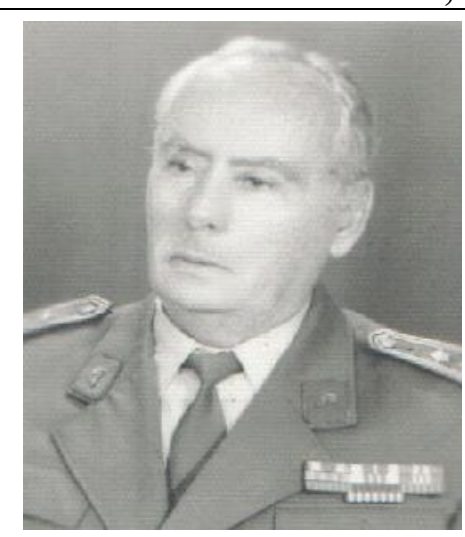 \\ Dr. Risto Ivanovski was born on Apr 15, 1914 in Prilep, R. Mace- donia. He completed High School in Bitola and graduated at the FM- Belgrade in 1942. After the liberation he applied to be a volunteer in the Yugoslav People's Army. He completed two-year specialization in 1947 and became anesthesiologist for the needs of the Army in Belgrade. A few months later he moved to Zagreb up to 1954 when he came back to Skopje. He was employed at the Military Hospital-Skopje which was the teaching base of the FM-Skopje at that time. \\ Dr. Risto Ivanovski was elected as an Assistant Professor at the FM-Skopje in 1959 and participated in the teaching process of anesthesiology in the framework of the subject of surgery. He was also a visiting professor for anesthesiology in Prishtina. \\ His contribution to the development of anesthesiology in R. Macedonia is enormous. He was one of the three educated anesthesiologists in Yugoslavia, since 1948. From 1954, when he came in Skopje, he developed the anesthesiology as an independent medical field. In 1955 together with Dr. Djurgja Klajic performed the first endo-tracheal intubation in Macedonia at the Surgical Clinic. He was teacher of the first generations of anesthetists and later the teacher of the doctors-anesthesiologists, too. \\ - He stayed at the Military Hospital up to 1978, when he was retired as a colonel. \\ Dr. Risto Ivanovski died in Skopje in 2013 at the age of 99.}


In 1946, Yugoslavia as a part of the antifascist coalition received aid in medical personnel and equipment (Forreger anaesthesiology equipment of American origin -) through the United Nations Relief and Rehabilitation Administration (UNRRA) in order to help the numerous and badly treated war injuries that led to disabilities of different kinds in many young people.

Dr. Patrick Shackleton and Dr. Rasel Davis from Great Britain were among the wellknown anaesthesiologists who came to Yugoslavia from the western countries. Thus the education of the first group of Yugoslav doctors in the field of anaesthesiology started at Prof. Arneri's Clinic for Plastic Surgery in Belgrade [8-10]. Dr. Risto Ivanovski was in this group and he is considered to be the founder of anaesthesiology in R. Macedonia and Croatia $[2,4,11]$.

From 1954, Dr. Ivanovski and Dr. Gindzberg, a well-known thoracic surgeon, were sent together to the Military Hospital in Skopje to organize the modern surgical and anaesthesiology service in Macedonia. For this period of his life Dr. Ivanovski said in his memoirs: "Then the Military Hospital in Skopje gathered several good surgeons (Dr. Pakik, Dr. Pishat, and
Dr. Bedekovic) so thoracic and abdominal surgery started. The patients for thoracic surgery were mainly suffering from tuberculosis of the lungs, so thoracoplasty, lobectomy and pulmectomy were performed. All of them were "high risk" patients, so I had to use some methods new for that time, for example "emphasized narcosis" with Laboret's cocktail and (or) immersion hypothermia. In those years we applied the highest number of anaesthesia procedures in hypothermia in Yugoslavia ... ".

Dr. Gjurgja Klajic has an important role in the beginnings of modern anaesthesia in $\mathrm{R}$. Macedonia. She was a part of the team of surgeons lead by Prof. B. Oberhofer, who were sent to Skopje in 1954 from Croatia and other republics of Yugoslavia, with the purpose of developing surgery and improving the health care in the country [12]. She was educated in anaesthesia in Zagreb and gave the first general anaesthesia in the operating theatre at the Surgical Clinic in Skopje. She also, with Dr. R. Ivanovski, performed the first endo-tracheal intubation for general anaesthesia.

Certainly, the most important person in the development of anaesthesiology as a science in R. Macedonia is Prof. Dr. Vladimir Andonov (Box 2), [13-16].

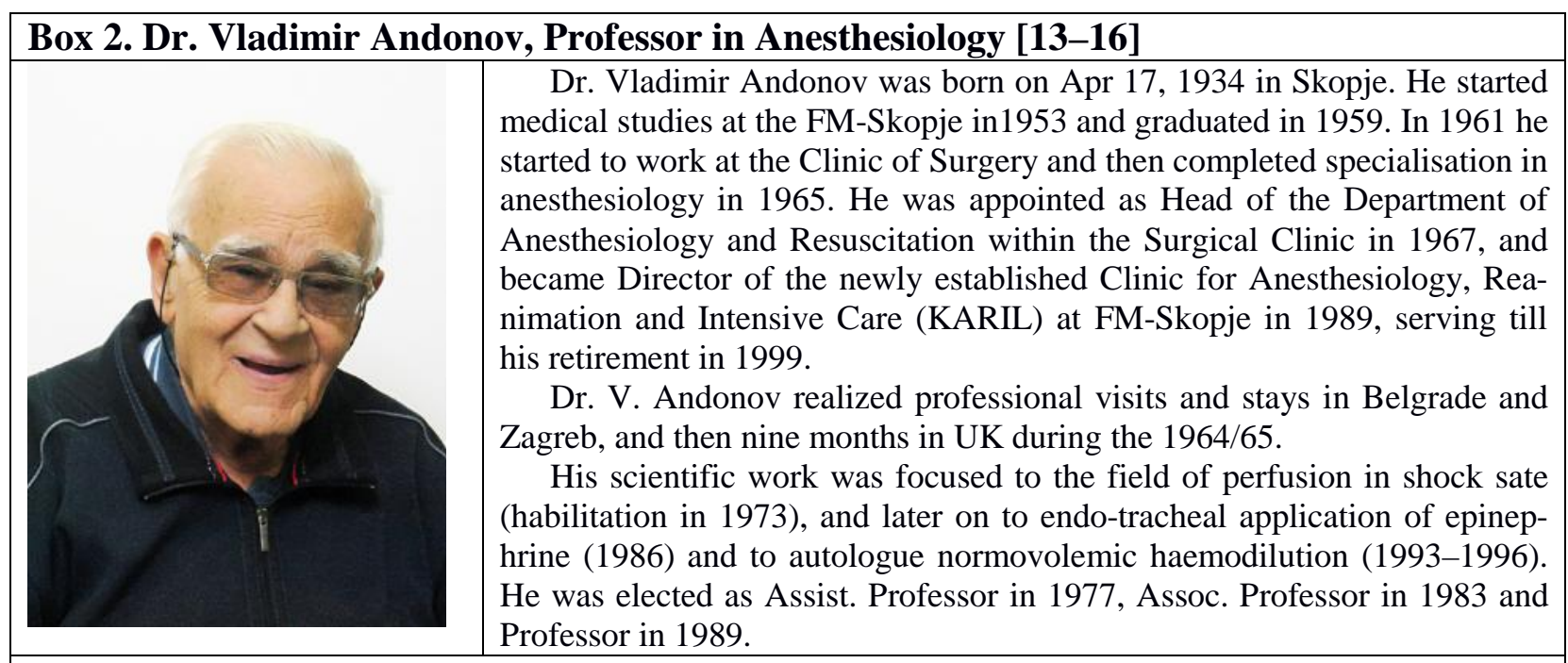

Prof. Andonov introduced numerous new methods and innovations in the field of anesthesiology and intensive care. He got several recognitions of merit and awards, among them the highest honors - medal with silver star in 1963 and the government award "Ss. Kliment Ohridski" in 2003. He is author of 76 scientific articles and 5 books.

Prof. Dr. Vladimir Andonov lives in Skopje at the age of 80 years.

The first specialists in anaesthesiology in Macedonia who served the needs of the Surgical Clinic in Skopje in 1965 were Dr. Vladi- mir Andonov and Dr. Vujica Stojanovic. In the same year Dr. Pavle Mitrevski was employed at the Medical Centre in Bitola. The programme 
for specialization lasted for three years. Doctors who became specialists in anaesthesiology in the subsequent years until 1974 are presented in Tab. 1.

Table 1

The first group of anaesthesiologists who completed specialization at the Faculty of Medicine in Skopje in the period 1965-74 [17]

\begin{tabular}{|c|c|c|}
\hline Name and Surname & Year of specialization & $\begin{array}{r}\text { Institution of employment } \\
\end{array}$ \\
\hline Vladimir Andonov & 1965 & Clinic for Surgery, Skopje \\
\hline Vujica Stojanovic & 1965 & Clinic for Surgery, Skopje \\
\hline Pavle Mitrevski & 1965 & General Hospital, Bitola \\
\hline Ilija Dubrovski & 1967 & Clinic for Surgery, Skopje \\
\hline Nikola Serafimovski & 1967 & City Hospital, Skopje \\
\hline Avram Balabanov & 1967 & City Hospital, Skopje \\
\hline Petar Nikolov & 1968 & City Hospital, Skopje \\
\hline Milorad Janevski & 1968 & Clinic for Gynaecology and Obstetrics, Skopje \\
\hline Sime Simovski & 1969 & General Hospital, Prilep \\
\hline Agica Stankova & 1969 & Clinic for Gynaecology and Obstetrics, Skopje \\
\hline Roza Ivanova & 1970 & Clinic for Surgery, Skopje \\
\hline Slavko Bakrachevski & 1970 & General Hospital, Ohrid \\
\hline Kudjan Hamporcum & 1970 & City Hospital, Skopje \\
\hline Ljiljana Lazarevska & 1970 & Clinic for Surgery, Skopje \\
\hline Boris Micevski & 1970 & Clinic for ORL, Skopje \\
\hline Nikola Mishkovski & 1971 & Clinic for Gynaecology and Obstetrics, Skopje \\
\hline Zika Urdarevic & 1971 & City Hospital, Skopje \\
\hline Ilinka Trajkovic & 1972 & General Hospital, Kumanovo \\
\hline Radislav Kalenikov & 1972 & City Hospital, Skopje \\
\hline Atanas Stevkov & 1972 & General Hospital, Strumica \\
\hline Stojan Nichevski & 1972 & General Hospital, Stip \\
\hline Dimitar Sekulovski & 1972 & General Hospital, Bitola \\
\hline Srboljub Mitrovic & 1973 & Clinic for Gynaecology and Obstetrics, Skopje \\
\hline Simeon Janevski & 1974 & General Hospital, Veles \\
\hline Lazar Shendov & 1974 & Clinic for Orthopedic Surgery, Skopje \\
\hline Marija Sholjakova & 1975 & Clinic for Surgery, Skopje \\
\hline Pantelej Donev & 1975 & General Hospital, Bitola \\
\hline Trajanka Trajkovska & 1975 & Clinic for Surgery, Skopje \\
\hline Vera Shikova & 1975 & Clinic for Surgery, Skopje \\
\hline Milica Spasova & 1974 & Clinic for Surgery, Skopje \\
\hline
\end{tabular}

Up to 1985 , the number of anaesthesiologist doctors exceeded 100, while today in Macedonia there are more than 250 anaesthesiologists [17].

\section{The role of $\mathrm{WHO}$ in the development of anaesthesiology in R. Macedonia}

It is important to note that in the $1960 \mathrm{~s}$ the WHO organized courses in anaesthesia for doctors from Member States, with scholarships for professional stays in Denmark. During this time in Denmark, a great number of patients remained with bulbous paralysis after the great epidemic of poliomyelitis in the late 1950s. In order to treat them, the first artificial ventila- tion techniques were developed there and, later, these techniques became the basis of modern intensive care. Several doctors from Macedonia were sent and took a one-year course in anaesthesiology in Copenhagen, Denmark: Dr. Spasko Guchev (a surgeon), Dr. Pavle Mitrevski, Dr. Ljupcho Vasilev, and Dr. Nikola Serafimovski.

Dr. Spasko Guchev was later the first Head of the Department of Anaesthesia at the Surgical Clinic, Dr. Pavle Mitrevski continued to work and develop anaesthesiology in Bitola, Dr Ljupcho Vasilev remained as a urologist, and Dr. Nikola Serafimovski served as anaesthesiologist at the City Surgical Hospital in Skopje, from where he went to work in Den- 
mark. This period was also marked by the professional stays of a few specialists in the UK. Dr. Risto Ivanovski was awarded a British Council scholarship for specialization in Edinburgh. Dr Vladimir Andonov attended a one-year specialization at St George's Hospital in London. Later in 1983, Dr. Lazar Shendov was attached to St Thomas Hospital and Dr. Marija Sholjakova spent one year at the Department of Anaesthesiology at the Royal Postgraduate Medical School, Hammersmith Hospital.

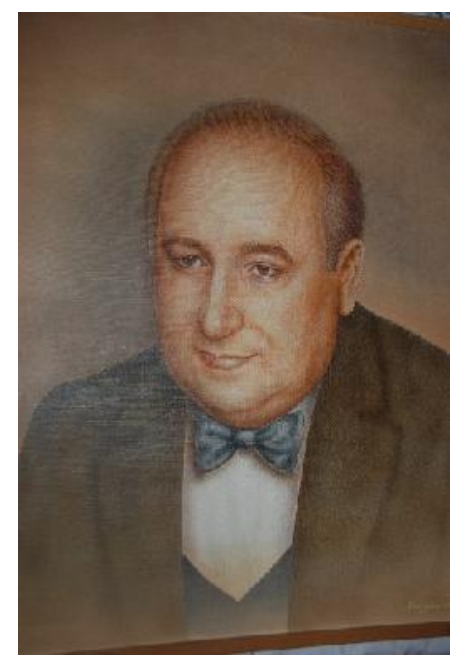

Figure 1 - Prof. Dr. Spasko Guchev

First Chief of the Department of Anesthesiology at the Surgical Clinic in Skopje (1961-1963)

\section{The beginnings of modern anaesthesia} in R. Macedonia

Modern anaesthesia in R. Macedonia began in 1965 when new, modern drugs for anaesthesia were introduced into everyday practice by the first specialist doctors in anaesthesiology. Besides ether, some new inhaling anaesthetics were introduced, i.e. Halothane (Fluothane) and Trilene. Pentothal - a barbiturate with a quick and short effect and succinyl choline (Leptosuccin), as a depolarized relaxant agent, started to be used. For a certain period the gas anaesthetic cyclopropane $(\mathrm{C} 3 \mathrm{H} 6)$ was used. Cyclopropane was an anaesthetic with good characteristics, but because of its potential explosiveness in conditions of sparking, its period of use was limited. Curare (D-tubocurare) began to be used during this period, and it was later replaced by another non-depolarized relaxant, namely Flaksedil. The so-called "azeotropic mixture" was also present with volumes of ether (2/3) and halothane (1/3). Nitric oxide started to be used routinely in early 1970s, when it became easy available because its production started in Slovenia. Ketamine (Ketalar) and Viadril (Viadril-G) appeared then. In the early 1970s neurolept anaesthesia (NLA) as a combination of the analgesic Fentanyl and the neurolepetic component Dehydrobenzperidol began to be used.

The use of the non-depolarized relaxant pancuronium bromide (Pavulone) took a dominant place in improving the quality of anaesthetics in the late 1970s, and even in the 1990s the palette of miorelaxants was extended with other drugs (Vecuronium, Atrakurium, Cisatrakurium, etc.). These years were also characterized by the modification of neurolept anaesthesia in balanced anaesthesia when the neuroleptic component was replaced by benzodiazepines. Also in the 1990s, Propofol was introduced instead of barbiturates for the introduction to anaesthesia. In many Macedonian hospitals combinations of opioid analgesics with volatile anaesthetics were implemented. In 1992 Isoflurane was introduced for routine use and it became dominant, together with Halothane, up to the early years of two thousand, when the use of Sevoflurane began.

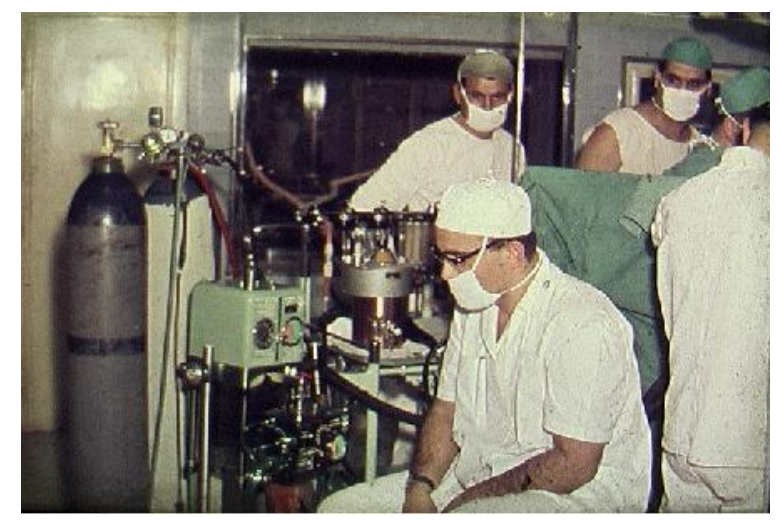

Figure 2 - Prof. V. Andonov at the operating room

After the introduction of NLA the monitoring in the operating theatres slowly began to improve, first at the University Clinics, and then in the Medical Centres. ECG monitoring became obligatory and later pulse oximetry, and soon monitoring (capnography etc.) began to be expanded. The year 1997 is significant for the improvement of patient safety because Dr. Dimitar Sekulovski opened the first Anesthesiology Out-patient clinic for preoperative assessment, in Bitola. In the next ten years such an organizational unit has become an obligatory part of each Anaesthesiology Department. 
The use of local/regional anaesthesia in $\mathrm{R}$. Macedonia is in accordance with the global trends in this area. From modest beginnings before World War II, the era of expansion of new drugs and equipment for general anaesthesia came in the $1960 \mathrm{~s}$, and the regional anaesthesia techniques were put in second place.

Modern regional anaesthesia started by performing central neuroaxial blocks, mostly spinal anaesthesia. The Clinic for Orthopaedic Surgey in Skopje is important in terms of its large scale use, when Prof. Dr. Lazar Shendov introduced spinal anaesthesia into daily use in 1975 [18]. Later the group of orthopaedic anaesthetists (P. Georgiev, J. Nojkov, J. Nancheva) improved the quality of spinal anaesthesia and expanded its use in paediatric patients. The first epidural blocks for painless childbirth were given by Dr. Srboljub Mitrovic at the Gynaecology and Obstetrics Clinic in Skopje in the late 1980s, but the obstetricians opposed this use because of continuation of deliveries and complications. Although, in the second half of 1990s, these interventions, as well as performing Caesarean section in spinal anaesthesia, became a routine, firstly at the Gynaecology and Obstetrics Clinic - (Prim. Dr. Lidija Grbevska and Prim. Dr. Atanas Sivevski), and then more widely. The first epidural catheter was placed in 1983 by Prof. Dr. V. Andonov, and since then this technique has been used mostly in combination with general anaesthesia for extensive surgery or in the treatment of pain in patients. Later on in the same year (1983), Prof. Dr. M. Sholjakova applied morphine in the epidural space for postoperative analgesia. In recent years, the use of regional anaesthesia and analgesia have been expanded particularly in the peripheral blocks.

Anaesthesia for kidney transplantation was introduced in the 1980s by Dr. Rose Ba-
shevska-Ivanovska together with Dr. Vera Shikova. Cadaver transplantation was developed later and Dr. Petar Duljanov, as an anaesthesiologist, made his unselfish contribution.

Cardio-anaesthesia in R. Macedonia dates back to 1973, when the so-called "stress-free anaesthesia" (high doses of morphine or fentanyl) was applied. The first anaesthesia for open heart surgery was given by Prof. Dr. V. Andonov and later, up to the 1990s, Prof. Dr. Trajanka Trajkovska gave 74 anaesthesia procedures in a series. Also, her particular contribution was the introduction of anaesthesia techniques for operations of the trachea and oesophagus.

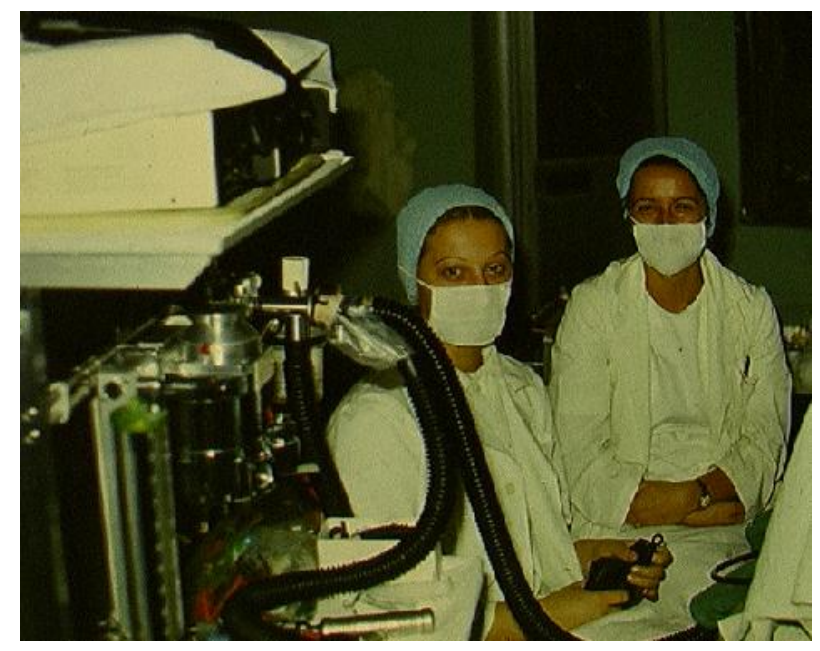

Figure 3 - Prof. M. Sholjakova at the operating room

The period 1992-2014 is characterized by the very fast development of modern anaesthesiology in R. Macedonia. Many new and innovative methods in the field of anaesthesiology and intensive care were introduced in support of surgical and other procedures at various university clinics at the Faculty of Medicine in Skopje and other institutions in Skopje and in R. Macedonia (Tab. 2).

Table 2

Innovations in the field of anaesthesiology and intensive care introduced in R. Macedonia in the period 1992-2014 [18-24]

\begin{tabular}{|c|c|c|c|c|}
\hline $\begin{array}{c}\text { Anaesthetic } \\
\text { technique }\end{array}$ & Surgical procedure & $\begin{array}{c}\text { Year of } \\
\text { introduction }\end{array}$ & Anaesthesiologist/s & $\begin{array}{c}\text { University Clinic/ } \\
\text { Hospital facility }\end{array}$ \\
\hline $\begin{array}{c}\text { New generation of } \\
\text { halogen inhalation } \\
\text { anaesthetics }\end{array}$ & $\begin{array}{c}\text { Isoflurane in major } \\
\text { surgery }\end{array}$ & 1992 & $\begin{array}{c}\text { M. Sholjakova and } \\
\text { colleagues at KARIL, } \\
\text { UCMF, Skopje }\end{array}$ & $\begin{array}{c}\text { KARIL, UCMF, } \\
\text { Skopje }\end{array}$ \\
\hline
\end{tabular}


Vladimir Andonov, et al.

\begin{tabular}{|c|c|c|c|c|}
\hline $\begin{array}{l}\text { Epidural anesthesia } \\
\text { and (Lidocain, } \\
\text { cystocaine) }\end{array}$ & Painless childbirth & 1993 & Srbo Mitrovich & $\begin{array}{c}\text { Clinic of } O b \& G \\
\text { Skopje }\end{array}$ \\
\hline $\begin{array}{l}\text { Basic monitoring in } \\
\text { anaesthesia }\end{array}$ & $E C G, N B P, P R$ & 1994 & $\begin{array}{l}\text { All specialists in } \\
\text { anaesthesiology }\end{array}$ & $\begin{array}{l}\text { All clinical centres in } \\
\qquad R M\end{array}$ \\
\hline $\begin{array}{l}\text { Anesthesia in difficult } \\
\text { position }\end{array}$ & Spinal surgery & 2004 & $\begin{array}{c}\text { Petar Achkovski } \\
\text { Marina Temelkovska } \\
\text { Mirjana Petrovska }\end{array}$ & $\begin{array}{l}\text { Clinic of Trauma and } \\
\text { bone reconstruction }\end{array}$ \\
\hline Neuro-anaesthesia & $\begin{array}{l}\text { Coiling procedures } \\
\text { in aneurysm surgery }\end{array}$ & 2005 & $\begin{array}{c}\text { Zlate Shuplinovski } \\
\text { Vesna Durnev } \\
\text { Ljupka Momirovska }\end{array}$ & $\begin{array}{c}\text { Clinic of } \\
\text { Neurosurgery }\end{array}$ \\
\hline $\begin{array}{l}\text { Management of brain } \\
\text { death }\end{array}$ & $\begin{array}{c}\text { Cadaveric } \\
\text { transplantation }\end{array}$ & $\begin{array}{l}1988 \\
2006\end{array}$ & $\begin{array}{c}\text { Petar Duljanov } \\
\text { Jovan Janchulev } \\
\text { Maja Mojsova }\end{array}$ & Clinic of Urology \\
\hline $\begin{array}{l}\text { Controlled and } \\
\text { monitored sedation } \\
\text { and analgesia }\end{array}$ & $\begin{array}{c}\text { Orthopaedic, plastic } \\
\text { and reconstructive } \\
\text { surgery }\end{array}$ & 2007 & $\begin{array}{c}\text { Jordan Nojkov } \\
\text { Jasminka Nancheva } \\
\text { Anton Damevski } \\
\text { Danica Pendovska } \\
\end{array}$ & $\begin{array}{c}\text { Orthopedic Clinic } \\
\text { and Plastic and Re- } \\
\text { constructive Surgery } \\
\text { Clinic } \\
\end{array}$ \\
\hline $\begin{array}{c}\text { Euthermia, preopera- } \\
\text { tive active compres- } \\
\text { sion-decompression } \\
\text { of limbs }\end{array}$ & Digestive surgery & 2008 & $\begin{array}{c}\text { Biljana Kuzmanovska } \\
\text { Andrijan Kartalov } \\
\text { Tanja Spirovska }\end{array}$ & $\begin{array}{c}\text { Clinic of Digestive } \\
\text { Surgery }\end{array}$ \\
\hline $\begin{array}{c}\text { Paediatric } \\
\text { anaesthesia with } \\
\text { servofluorane }\end{array}$ & $\begin{array}{c}\text { Liver } \\
\text { transplantation }\end{array}$ & 2011 & $\begin{array}{l}\text { Ljupcho Donev } \\
\text { Vesna Durnev }\end{array}$ & $\begin{array}{l}\text { Clinic of pediatric } \\
\text { surgery }\end{array}$ \\
\hline $\begin{array}{l}\text { Cardiac perfusion } \\
\text { in child }\end{array}$ & $\begin{array}{l}\text { Paediatric cardio- } \\
\text { surgery }\end{array}$ & 2013 & $\begin{array}{l}\text { Ljupcho Donev } \\
\text { Albert Leshi }\end{array}$ & $\begin{array}{c}\text { Clinic of pediatric } \\
\text { surgery }\end{array}$ \\
\hline $\begin{array}{l}\text { Bariatric surgery and } \\
\text { ultrasound TAP Block }\end{array}$ & Digestive surgery & 2013 & $\begin{array}{c}\text { Darko Sazdov } \\
\text { Andrijan Kartalov }\end{array}$ & $\begin{array}{l}\text { Clinic of Digestive } \\
\text { Surgery }\end{array}$ \\
\hline
\end{tabular}

In 1992, the first laparoscopic cholecystectomy was performed at the Digestive Surgery Clinic and the anaesthetic support was provided by Dr. Vera Shikova.

The first block of the brachial plexus was applied in 1994. If we exclude the old beginnings, when Novocaine, procaine, tropocaine (Prilep, 1953) [25] were used as local anaesthetics, the new era of local/regional anaesthesia began with the use of lidocaine and from the 1990s with the use of bupivacaine, too. Caudal block was first applied by the paediatric anaesthetists (Dr. V. Milosheva, Dr. B. Velkovski, Dr. B. Popovska Dr. A. Kartalov, and Dr. Lj. Donev) in the late 1990s.

The first Centre for the Treatment of Chronic Pain, as a separate unit, was opened at the Orthopaedic Surgery Clinic by Prof. Dr. L. Shendov in 1997. Today the treatment of pain has been realized in many institutions, including private hospitals, but generally it is still insufficient compared to global trends.

Since 2000, several private hospital complexes ("Philip II", "Remedika", "Sistina" etc.) have been established successively. This has caused a "brain drain" of experienced anaesthe- siologists of the middle generation from many public health institutions, but primarily from the University Clinic for Anaesthesia, Reanimation and Intensive Care (KARIL). This did not reflect remarkably on the quality and quantity of anaesthesia and intensive care. Although there was a drain of half of the specialists in anaesthesiology it should be noted that in this period the scope of work increased, so Prof. Z. Nikolova Todorova supported the specialists who stayed in KARIL. These circumstances are certainly an important part of the history of anaesthesiology. The generations who followed deserve special appreciation because they overcame this artificially created personnel deficit, and in a short period of time the situation improved. On the other hand, private health care facilities with investments in equipment, combined with highly professional medical staff attracted by higher incomes, led to a qualitatively new level of development of modern anaesthesia departments and levels of services in the field of intensive treatment.

In the last decade, a series of innovations in the field of anaesthesiology and intensive care have also happened, especially in the field 
of transplantation and cardiac surgery. Today, the Macedonian cardio-anaesthesiologists successfully perform anaesthesia in the private cardio-surgery hospitals "Filip II" and "Sistina".

\section{Development of intensive care in Macedonia}

The first intensive care unit (or "shock room", as it was called at the time) was established in 1955 as a part of the Surgical Clinic in Skopje for the needs of intensive monitoring of patients with heart operations that were performed at that time.

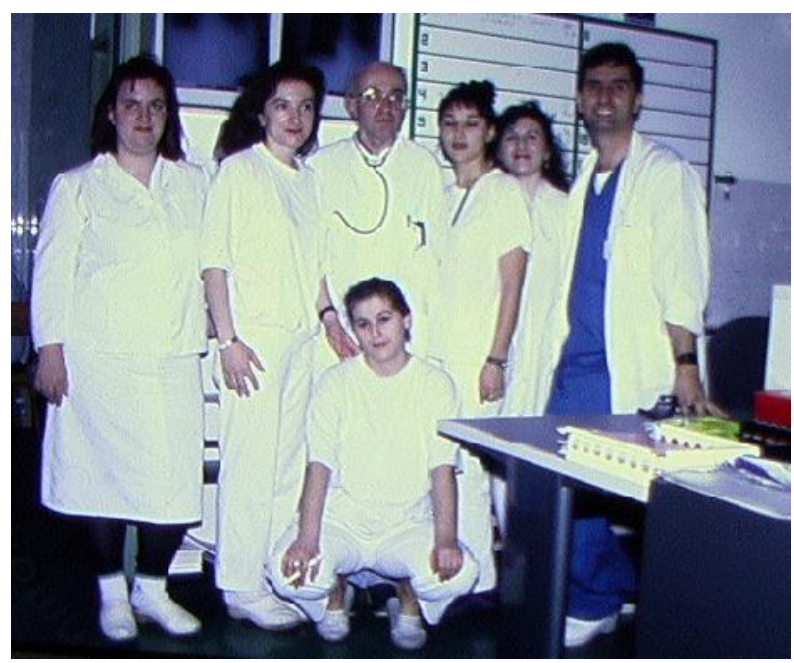

Figure 4 - At the new ICU

Beginnings in the true sense of the term "intensive care" dated back to 1966 when an Intensive Care Ward was established at the Surgical Clinic. Then a modern approach to critical patients started. Prof. Dr. Vladimir Andonov introduced the artificial ventilation in critical patients with ventilator (type Mainly) for the first time. Later, several types of ventilators (Bird, Dragger) were provided. In the first years of artificial ventilation used on patients there were different opinions about their utility. There were loud remarks that death would take its turn for sure in these patients. A year or two must have passed while the surgeons themselves began to demand certain patients be placed on artificial mechanical ventilation. We should point out the fact that Prof. Dr. V. Andonov in cooperation with grad. eng. J. Andonov invented two prototypes of the socalled transistorized respirator $(2 \times \mathrm{A})$. This respirator was patented on a federal level. In the subsequent years, intensive care wards were opened in other surgical institutions (first in Bitola and in the surgical hospital of the city of Skopje), as well as in many non-surgical wards (cardiology, neonatology, pulmology, internal wards in medical centres, etc.). There was a lack of specialists with experience in intensive care in the non-surgical wards, so the first generations of anaesthesiologists were daily engaged in performing invasive procedures.

\section{Establishment of the Clinic for Anaesthesiology, Reanimation and Intensive Care}

Intensive treatment experienced its real bloom with the establishment of the Clinic for Anaesthesiology, Reanimation and Intensive Care (KARIL) in 1989. Prof. Dr. V. Andonov was the first director of KARIL. In January 1993 the new Intensive Care Unit (ICU) was established as part of the newly built facility of the Surgical Clinics. Conditions for enormous progress in the care of critically ill patients receiving mechanical ventilation were created there with the new facilities, new ventilators and monitoring of the Siemens brand. Some contemporary methods in the treatment of critically ill patients and intensive care were introduced by Prof. Dr. Zorka Nikolova Todorova, who served as Director of the ICU from 20062013.

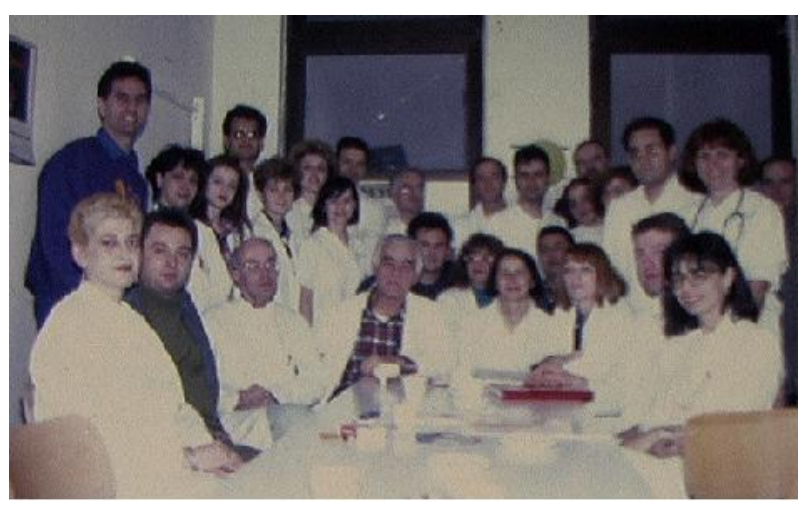

Figure 5-KARIL's staff in 1995

Since 1993 the Clinic of Cardiology has had new ventilators for intensive care and has collaborated with anaesthesiologists from KARIL in order to develop skills in the application of mechanical ventilation (Dr. Vladimir Janakievski, etc.). In 1996 the City Hospital in Skopje and the Medical Centres in Bitola and Shtip equipped their intensive care wards with equip- 
ment from the Acoma company donated by the Japanese government. In the following years the intensive care wards in other hospitals in Macedonia were more or less equipped.

The Clinic for Infectious Diseases historically had the first "tank ventilator" in the 1960s, but the introduction of mechanical ventilation as a synonym for ventilation under positive pressure was initiated by Prof. Dr. Milenkovic and his team nominated to work in the new intensive care ward. Doctors, specialists in infectious diseases, were sent to ICU-KARIL (Dr. Krste Grozdanovski, Dr. Marija Cvetanovska, Dr. Valerija Kirovska, and Dr. Sanja Marinkovic) in order to learn the basic principles and procedures of intensive care and start to work independently in their new intensive care unit. During the H1N1 virus outbreak (20092010), this cooperation achieved its peak and gave positive results in improving the skills for performing mechanical ventilation at the Infectious Diseases Clinic.

In October 1995, after the attempt on his life, the President of R. Macedonia, Mr. Kiro Gligorov, was admitted for treatment at the new facilities of the newly opened ICU of KARIL. The entire anaesthesia team (10 doctors and 10 nurses) made their professional contribution to saving the life of the President. They were constantly present by his side for 24 hours and Prim. Dr. Jovan Janchulev remained his personal physician until the end of the President's life.

Patients with respiratory failure from many clinics (Neurology, Pulmology, Gastroenterology, Nephrology, Toxicology, and Paediatrics) were treated in the central unit for intensive care - KARIL, besides the surgical patients. Concerning this, there were different opinionsas to whether only surgical patients should be treated in ICU or patients with different etiologies who need therapy with an artificial ventilator should be treated also. The mutual cooperation between ICU - KARIL and the newly opened ICU at the Paediatric Diseases Clinic should be also noted. The anaesthesiologists from KARIL gave strong support to overcome the basic difficulties that the paediatricians-intensive care doctors encountered in that period.

In September 2000, a section for the intensive care of neurosurgical patients (Head Prof. Dr. M. Sholjakova) was established. That same year, by the establishment of the "Filip II" private cardiac surgery hospital, the intensive treatment obtained a new quality because for the first time several contemporary invasive procedures were introduced there. For a certain period of time this hospital served as a training base for postgraduate studies for cardio-anaesthesia (2001-2007).

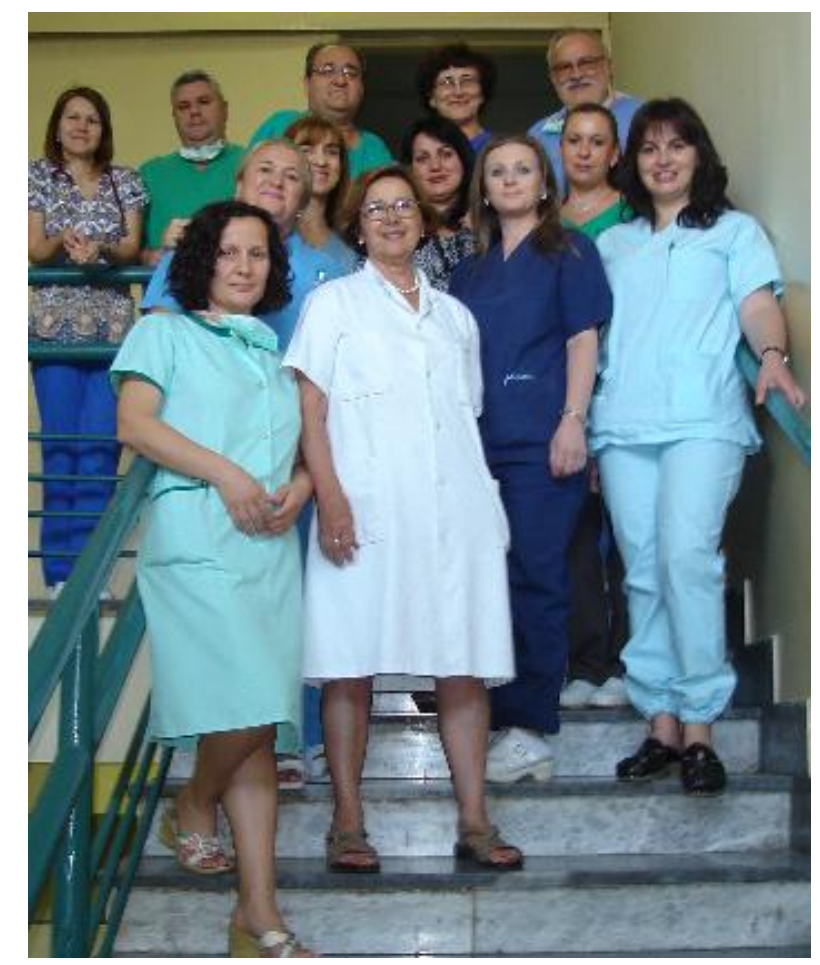

Figure 6 - The staff from KARIL

In 2011, the Paediatric Surgery Clinic, led by Dr. Risto Simeonov in active collaboration with Dr. Vladimir Chadikovski, opened a specialized paediatric ICU with 4 ventilators. It was a new challenge for anaesthesiologists in the area of anaesthesiology and intensive treatment (the first liver transplantation was performed on a child, on September 12, 2011). Transplantation of kidneys in children has also become a regular practice, and on April 8, 2013 the project for State Children's cardiac surgery began.

A special event in the development of this area of medicine is the formation of the Association for Treating Critical Patients in the framework of the Macedonian Medical Association (MMA) in 2005. Initiated by Prof. Dr. Zorka Nikolova Todorova, this Association gathers physicians dealing with this branch of medicine in several areas (surgery, neonato$\operatorname{logy}$, cardiology, transfusiology, etc.) in order 
to analyse interdisciplinarily all the challenges of the specific medical fields.

Besides Prof. Dr. V. Andonov, there are other doctors who made significant contribution to the development of the intensive care in the country: Prof. Dr. Maria Sholjakova, Prof. Dr. Zorka Nikolova Todorova, and Prof. Dr. Trajanka Trajkovska, who were Heads of this Department at the Surgical Clinics, then Dr. Slavko Krstevski, Dr. Mirjana Shosholcheva, Ph.D., (City Hospital Surgery) and also Dr. Dimitar Sekulovski and Dr. Vlado Ristovski (Clinical Hospital, Bitola), and Dr. Sime Janevski (in the Military Hospital, Skopje).

\section{Professional and educational activities of anaesthesiologists from Macedonia}

Continuous medical education for anaesthesiologists started very early, namely in the period when anaesthesiology procedures started to be in the hands of doctors. Since Macedonia was then one of the republics of the Former Yugoslavia, it was normal that the beginnings were mutual for all republics. Thus, the First Congress of Yugoslav Anesthesiologists was held in Belgrade in 1969. The Association of Anaesthesiologists from Yugoslavia (JUARIL) was formed then from the existing sections in the Republics. The Association decided that every second year intersection meetings (mini congresses) should be held and every four years a congress should be organized and a new President of JUARIL should be elected.

During this period from 1969 to the present three intersection meetings and one
Congress have been held in Macedonia. Intersectional meetings were held in 1971 (in Ohrid, Prof. Dr. V. Andonov), in 1979 (Skopje, Dr. B. Micevski) and in 1988 (Bitola, Dr. D. Sekulovski). In 1981 the 4th Congress of Yugoslav Anaesthesiologists was held in Ohrid, when Prof. Andonov was elected as President of JUARIL for a four-year term.

The continuity of having professional congresses has been retained following independence in 1990, when R. Macedonia became an independent state. The existing Section developed into the Society of Doctors of Anaesthesiology, Reanimation and Intensive Care the Macedonian Society of Anaesthesiologists (MSA). Prof. Dr. Jordan Nojkov was elected as the first President of the Society for a period of two four-year terms (1990-1998). Immediately after independence (1990), MSA was admitted as a full member of the World Federation of Anaesthesiology Associations (WFSA) during the presidency of Johan Zorab, at a meeting in London, and in the next year MSA became a member of the World Federation of Societies for Intensive Medicine (WFSICCM ) [26, 27].

The 1st Congress of Macedonian anaesthesiologists with international participation was held in Ohrid in 1995 and the President of the Organizing Committee was Prof. Dr. Jordan Nojkov. The subsequent Macedonian congresses with international participation and other international gathering and educational courses of anaesthesiologists in R. Macedonia up to 2014 are presented in Table 3.

Table 3

Main professional gatherings and educational courses of anesthesiologists in R. Macedonia in the period 1995-2014

\begin{tabular}{|c|c|c|c|c|}
\hline Professional event & $\begin{array}{c}\text { Time (year) } \\
\text { when it was held }\end{array}$ & Venue & $\begin{array}{c}\text { President of the Organizational } \\
\text { board }\end{array}$ & $\begin{array}{c}\text { Output } \\
\text { document/s }\end{array}$ \\
\hline The 1st Congress & 1995 & Ohrid & Prof. Dr. Jordan Nojkov & Book of abstracts \\
\hline The 2nd Congress & 2000 & Ohrid & Ass. Prof. Dr. Violeta Milosheva & Book of abstracts \\
\hline The 3rd Congress & 2005 & Ohrid & Prof. Dr. Mirjana Shosholcheva & Book of abstracts \\
\hline The 4th Congress & 2010 & Ohrid & Ass. Prof. Dr. Jasmina Nancheva & Book of abstracts \\
\hline The 5th Congress & 2014 & Ohrid & Ass. Prof. Dr. Biljana Shirgovska & Book of abstracts \\
\hline Regional Meeting of ESRA & 1997 & Ohrid & Prof. Dr. Jordan Nojkov & Book of abstracts \\
\hline $\begin{array}{c}1^{\text {st }} \text { Balkan Congress of } \\
\text { Young Anaesthesiologists }\end{array}$ & 2003 & Skopje & Prof. Dr. Marija Sholjakova & Book of abstracts \\
\hline $\begin{array}{c}\text { FEEA, now CEEA* courses } \\
\text { FEA }\end{array}$ & $1998-2016$ & Dojran & $\begin{array}{c}\text { Prof. Dr. Marija Sholjakova, } \\
\text { Ass. Prof. Dr. Jasmina Nancheva }\end{array}$ & $\begin{array}{c}\text { I,II, III Cycle's } \\
\text { book in 6 courses }\end{array}$ \\
\hline
\end{tabular}


Vladimir Andonov, et al.

\begin{tabular}{|c|c|c|c|c|}
\hline $\begin{array}{c}\text { School of Intensive Critical } \\
\text { care courses }\end{array}$ & $2000-2014$ & Skopje & Prof. Dr. Zorka Nikolova Todorova & $\begin{array}{c}\text { Book of refresher } \\
\text { courses }\end{array}$ \\
\hline School of anesthesia courses & $2004-2006$ & Mavrovo & Prof Dr. Mirjana Shosholcheva & $\begin{array}{c}\text { Book of refresher } \\
\text { courses }\end{array}$ \\
\hline Difficult airway courses & $2010-2014$ & Skopje & Ass. Prof. Dr. Biljana Shirgoska & $\begin{array}{c}\text { Book of refresher } \\
\text { courses }\end{array}$ \\
\hline
\end{tabular}

* European foundation for education in anaesthesiology

The following anaesthesiologists have been presidents of the Macedonian Society of Anaesthesiologists since its foundation in 1962: Prof. Dr. Risto Ivanovski, Prof. Dr. Vladimir Andonov, Dr Milorad Janevski, Ass. Prof. Lazar Shendov, Dr. Petar Duljanov, Prim. Dr. Borche Micevski, Prim. Dr. Sime Janevski, Prim. Dr. Dimitar Sekulovski, Dr. Vujica Stojanovic, Prof. Dr. Jordan Nojkov, Ass. Prof. Dr. Violeta Miloshevska, Prof. Dr. Marija Sholjakova, Dr. Zvonko Krstevski, Prof. Dr. Mirjana Shosholcheva and Ass. Prof. Dr. Andrijan Kartalov.

MSA has managed to raise the level of education of Macedonian anaesthesiologists through organizing Sectional meetings and workshops where, besides lecturers from our country, there has been a regular participation by foreign lecturers from different areas of anaesthesiology and intensive care.

\section{Specialization and continuing medical education in anaesthesiology development in R. Macedonia}

Anaesthesiology, reanimation and intensive care are young branches of medical science which have been relatively lately involved in medical studies everywhere in the world. In Macedonia the scientific and educational activities concerning these branches went through the Department of Anaesthesiology at the Faculty of Medicine (FM) in Skopje, which began its activities in 1975. This Department was responsible for postgraduate studies and training for specialists, while teaching of students was realized in the framework of the subject of Surgery at the Department of Surgery. In 1998, Prof. Dr. M. Sholjakova was elected Vice Dean of the Medical Faculty in Skopje. Two years later, the Department became independent, and according to the Curriculum for undergraduate studies in medicine the students follow the subject of Anaesthesiology with Resuscitation as a separate course. The teaching activities of the
Department in the beginning consisted of teaching the subject of anaesthesiology with resuscitation for the students of medicine and dentistry. Additionally, in the last several years, teaching has been organized for students at the Higher Nursing School within the FM-Skopje. The Chair of Anaesthesiology also organizes lectures for medical first aid, lecturing for postgraduate studies for specialists, Masters degrees and doctoral studies. The tendency of the Chair in performing these educational activities is to give the students as much practical knowledge as possible in order to enable them to help all critically ill and injured patients in all phases of prehospital care in the future.

Specializations in anaesthesiology for doctors started in 1963 and lasted for three years in the beginning. In 1974 the duration was extended to 4 years, until 2007, when the Curriculum was adjusted according to European directives and it was extended to 5 years. Based on the inspected licensing in 1999 (again in 2004) by the special Committee of the Board of Anaesthesiology of the European Union for medical specializations, KARIL has received a Certificate that it fully meets the European standards for training of specializing doctors, and has received Accreditation as a European Centre for Education in Anaesthesiology.

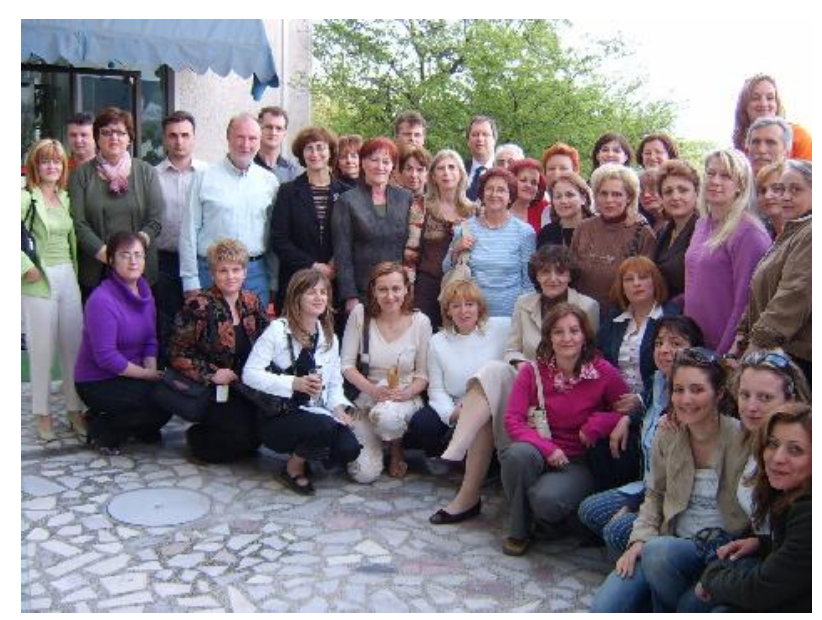

Figure 7 - Dojran Postgraduate School, 2002 
Since 1998 the Chair of Anaesthesiology has organized three-day courses (postgraduate school) every year for Continuing Medical Education and refreshing the knowledge of anaesthesiology, resuscitation, intensive care and pain therapy under the auspices of the European Foundation for Education in Anaesthesiology (FEEA, now CEEA). This educational programme was created by the European Board of Anaesthesiology. The programme is equally designed either for young specialists or specializing doctors. Having completed six courses, the participants acquire a European Diploma in Anesthesiology. Also, since the beginning of its existence (1994), the Chair has organized courses in reanimation for practitioners of different profiles, and lately other activities for the implementation of modern algorithms of the European Council for Resuscitation [28].

\section{Retired and currently employed lecturers in anaesthesiology in $R$. Macedonia}

Since its foundation, the following teachers were and some of them still are members of the Chair of Anaesthesiology with reanimation at the FM-Skopje: Prof. Dr. V. Andonov, Prof. Dr. M. Sholjakova, Prof. Dr. J. Nojkov, Ass. Prof. Dr. V. Milosheva, Prof. Dr. Z. Nikolova-Todorova, Prof. Dr. T. Trajkovska, Ass. Prof. Dr. L. Shendov, Prof. Dr. M. Shosholcheva, Ass. Prof. Dr. J. Nancheva, Ass. Prof. Dr. B. Shirgovska, Ass. Prof. Dr. Andrijan Kartalov and Ass. Prof. Dr. B. Kuzmanovska. At the Ss Kliment Ohridski University in Bitola, Ass. Prof. Dr. Vlado Dameski is teaching anaesthesiology, while at the Faculty of Medical Sciences and Higher Nursing School at the Goce Delcev University in Stip Dr. B. Eftimova and Dr. J. Jovanovska are lecturers in anaesthesiology.

The scientific activity of the Department from 1998 has been realized through three domestic and one international project, and numerous other investigations which resulted in 14 doctorates, dozens of Master's degrees and many professional and scientific papers. The members of the Department have published 11 books on anaesthesiology and reanimation and 6 collections of lectures as well as a textbook for medical students.

\section{Limitation of the study}

This study used published papers and other materials related to the area of anaesthesiology, as well as oral recollections of participants who have worked in the field of anaesthesiology in the past. Unfortunately, the number of such studies is very small. Archive materials are missing, especially for the period between the two world wars and immediately after. The authors tried to find documents from that period in historical archives (published papers, operational protocols, lists), but unfortunately with only limited success. It remains for future generations to elucidate this period in more details.

\section{Conclusion}

The development of anaesthesiology in R. Macedonia has had a trend of permanent improvement since its first beginnings in the 1950s. Starting out from being a helping tool in the hands of a surgeon, today it has grown into a highly technological and independent medical branch, necessary in everyday work in any modern hospital. As in no other discipline, anaesthesiology involves contemporary knowledge of pathological physiology and advanced forms of high medical technology in order to support the vital functions of the patient during an operation or in patients with critical illness.

Macedonian anaesthesiology has common roots with the anaesthesiology with the states which have emerged from the former Yugoslavia. The pioneer of Macedonian anaesthesiology, Dr. Risto Ivanovski, was one of three doyens - the founders of anaesthesiology in this area. His arrival in Macedonia in 1954 made possible the early introduction into practice of this science on modern principles.

In the further development of anaesthesiology, the activity of the Surgical Clinic at the FM-Skopje has taken the crucial place, as well as the Military Hospital and City Hospital in Skopje. The first generations of medical technicians - anaestheticians for Macedonia and Kosovo - were educated there. In later years (since 1965) more than 250 anaesthesiologist doctors have completed specialization and today they successfully perform this activity in hospitals throughout the country. These trained professionals from the Department of Anaesthesiology successfully face the challen- 
ges posed by the modern development of surgery and intensive medicine and make their contribution to the development of anaesthesiology as a science. Concerning the educational and scientific activities of the Department, the name of Prof. Vladimir Andonov should be mentionned, as well as his numerous successors who contributed to the development of this activity.

\section{REFERENCES}

1. Rupreht J, Keys TE. Anesthesia - Its Origins and Its Mission, ch.1.1. In: Rupreht J, et al. Eds. Anesthesia - Essays in its History. Springer-Verlag, Berlin, Heidelberg. 1985: 7-15.

2. Jukić M. Anaesthesiology activities in Croatia from the first ether narcosis in Zadar in 1847 to 2008 . Acta med-hist Adriat. 2010; 8(2): 365-76.

3. Soban D, Andonov V, Lalevic P, Ribarić L, Stajić A. The development of Modern Anesthesia in Yugoslavija, ch.4.15. In: Rupreht J, et al. Eds. Anesthesia - Essays in its History. Springer-Verlag, Berlin, Heidelberg. 1985: 253-7.

4. Džočkov J. The first anesthesiologist in Macedonia. [In Macedonian]. Vox Medici, Skopje. 2007; 6(16): 32-4.

5. Nojkov J. The founder of anesthesiology in Macedonia and Croatia (from the history of the Macedonian health - Dr Risto Ivanovski). [In Macedonian]. Vox Medici, Skopje 2013; 80(22): 47-9.

6. Nojkov J. The Oldest Anaesthesiologist on the Balkan Peninsula, Dr. Risto Ivanovski, Dies. Maced J Med Sci. 2013; 6(3): 296-8. http//dx.doi.org/10.3889/MJMS.1857-5773.2013.0304

7. Dragojević B, Andreevski A, Referees. Report on election of Assistant Professor in anesthesiology (Risto Ivanoski) at the Faculty of Medicine in Skopje. [In Macedonian]. Bulletin of the University in Skopje. No. 18, 1959: 7-12.

8. Davies P. Note on the history of anaesthesia in Yugoslavia. Anaesthesiologica Iugoslavica. 1989; 14(5-6): 5-8.

9. Kovačev S. First students at the Main Military Hospital in Belgrade. Anaesthesiologica Iugoslavica. 1989; 14(5-6): 8-10.

10. Vučović D. The history of Serbian Anesthesia. In: Vučovic D, ed. Anesthesiology I, Zavod za udzbenike Srbije, Beograd, 2014.

11. Begović-Sisul E, Cindrić-Stancin M, Ribarić Lj. Development of Anaesthesiology and Intensive Care in Rijeka. Acta Fac Med Flum. 2000; 25 (1-2): 79-83.

12. Polenakovic M, Donev D. Contributions of the doctors from Croatia in establishing and initial development of the Faculty of Medicine in Skopje, Republic of Macedonia. Prilozi-Contributions, Sec. Biol. Med. Sci., MASA. 2011; 32(2): 331-58 Available from: http://manu.edu.mk/prilozi/26p.pdf. Accessed: Sept 17, 2014.

13. Džočkov J. Heading - doyens (Prof. Dr. Vladimir Andonov). [In Macedonian]. Vox Medici, Skopje. 2011; 70 (20): 32-5.
14. Gučev S, Serafimov Lj, Hrisoho D, Dolgova-Korubin V, Nikodijević B, Referees. Report on election of Associate Professor in anaesthesiology (Vladimir Andonov) at the Faculty of Medicine in Skopje. [In Macedonian]. Bulletin of the University in Skopje. No. 411, 1983: 83-98.

15. Marenović T, Janjić I, Pečan M, Trajkov T, Jurukovski J, Referees. Report on election of Professor in anaesthesiology (Vladimir Andonov) at the Faculty of Medicine in Skopje. [In Macedonian]. Bulletin of the University in Skopje. No. 518, 1989: 127-32.

16. Ristovski B, Editor-in-Chief. Macedonian Encyclopedia, Part I. [In Macedonian]. Macedonian Academy of Sciences and Arts, Skopje. Skopje. 2009: 57. ISBN 987-608-023-4 (1).

17. Ministry of Health, Labor and Social Policy of the Republic of Macedonia. Register of Specialist Doctors - Anaesthesiology, Skopje. 1963.

18. Šendov L, Georgiev P, Nojkov J, Simjanovski M, Nančeva J, Maneva D. Two decades of regional anaesthesia application. 1st Congress of Anaesthesiologists from Macedonia, Ohrid, 25-28 May, 1995. Book of Abstracts: 59

19. Šoljakova M, Hasani A. Preemptive analgesia in children with Caudal Block, OAI, J of South African child anaesthesia. 2011; (2): 301.

20. Kartalov A, Kuzmanovska B, et. al. The effect of a small dose of Ketamine on postoperative analgesia and cytokine changes after laparoscopic cholecystectomy. Prilozi/Contributions, Sec. Biol. Med. Sci. MASA. 2012; 33(1): 217-29.

21. Marčevska M, Šoljakova M, Panov S, Cvetkovska B, Stefanovski I, Kartalov A. Effects of the pharmacological pre-treatment (Isoflurane) and Global Brain ischemia on the body temperature in experimental rats. Mac J Med Sci. 2008; 1(2): 31-5.

22. Kuzmanovska B, et al. Improvement of cerebral oxygenation during laparoscopy using intermittent sequential compression of legs. Prilozi/Contributions, Sec. Biol. Med. Sci. MASA. 2011; 32(2): 247-57.

23. Srceva M, Mojsova M, Kuzmaniovcsa B, Arsova A, Šoljakova M. Changes of haemodynamic parametars during anesthesia induction in patients treated with angiotenzin converting enzyme inhibitors. Physioacta. $2013 ; 7(2)$ : 53-63.

24. KARIL. Operative protocols - Anaesthesia 19922014. KARIL, UC of TORAICEC Skopje, 2014.

25. Šoljakova M. Audiovisual record from a round table for the history of anaesthesiology in Macedonia. 2nd Congress of Anaesthesiologists from R. Macedonia, Ohrid. 4-7 May, 2000.

26. Nojkov J. Anaesthesiology in Macedonia. World Anaesthesia - Newsletter of the World Federation of Societies of Anaesthesiologists. 1999; 3(2): 47-8.

27. Nojkov J. Anaesthesiology in Macedonia. Newsletter of the European Academy of Anaesthesiology. May 2000; 12: 7-8.

28. Žanteva-Naumovska M, Malevska-Ivanovska V. 60 years of the Faculty of Medicine - Department of Anaesthesiology, Reanimation and Intensive Care. Skopje, 2007: 127-9. 
Р е $з$ и м е

(

)

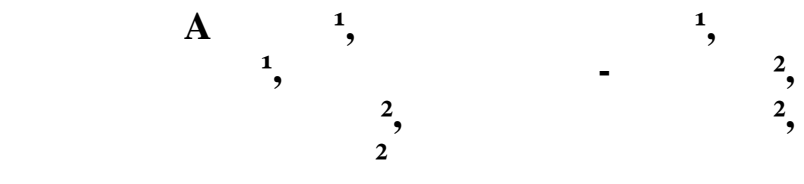

1 Медицински факултет, Универзитет

„Св. Кирил и Методиј“, Скопје, Р. Македонија; пензионирани професори, независни истражувачи 2 Клиника за анестезиологија, реанимација и интензивно лекување, Медицински факултет, Универзитет „Св. Кирил и Методиј“, Скопје, Р. Македонија

ел: Да се прикажат хронолошки најзначајните настани и актери што ја одбележаа историјата на анестезиологијата и интензивното лекување во Република Македонија од своите почетоци во 1950-тите години.

etod: Ретроспективна студија врз основа на архивски материјали, објавена литература и јубилејни изданија, како и сеќавањата на поединци кои работеа во областа на анестезиологијата во изминатиот период.

eзулt tu: Помеѓу двете светски војни, првите процедури во анестезијата беа извршувани од страна на хирурзите. По Втората светска војна, развојот на анестезијата во Република Македонија може да се подели на два периода: пред 1965 и по 1965 година. Пред 1965 година, анестезија, главно, даваа техничари обучени на курсеви, а по оваа година анестезиологијата беше преземена од анестезиолози кои специјализирале на Медицинскиот факултет во Скопје.

Во 1985 година имаше 100 анестезиолози, а денес нивниот број надминува 250. Најважни личности во историјата на македонската анестезиологија се: д-р Ристо Ивановски, кој работел од 1954 до 1978, и д-р Владимир Андонов, кој работел како анестезиолог од 1965 до 1999 година. Двајцата доајени придонесоа многу за развојот на анестезиолошката служба и едукација на анестезиолозите во Република Македонија.

Интензивното лекување започна во 1955 година, но во вистинска смисла се спроведуваше од 1966 година, кога се воведени вештачките вентилатори. Модерниот Оддел за интензивно лекување беше отворен на Клиниката за анестезиологија и реанимација во 1995 година и тоа беше следено и во други болници во државата. Одделот за анестезиологија постои на Клиниката за хирургија од 1975 година и тој даде огромен придонес во образованието на стручњаци кои ги применуваат современите принципи во ургентната медицина и интензивното лекување.

клучок: Од скромните почетоци во 1950тите години, анестезиологијата денес во Република Македонија се развива во добро организирана активност, која успешно ги следи трендовите на модерната медицина во областа на анестезиологијата, реанимацијата, интензивното лекување и лекувањето на болката.

лучни зборови: анестезиологија, реанимација, интензивно лекување, лекување болка, Република Македонија, историја. 